Chemical companies rebel

\section{Boston}

THE Bush administration's plans to modernize the United States' chemical weapons stockpile have stalled, according to information that surfaced from the Pentagon last week, because the two major domestic manufacturers of a key chemical ingredient have declined on ethical grounds to produce it. As a result, the administration must either forfeit this year's funding for the chemical modernization programme, or face the potential embarrassment of forcing the companies to sell the chemicals to the military.

Ironically, the US administration is now finding itself thwarted by the same strengthened corporate controls on restricted chemicals that it has long advocated to halt chemical-weapons proliferation abroad. Citing their own tightened corporate policies prohibiting the sale of materials for use in chemical weapons, the Occidental Petroleum Corporation and the Mobay Corporation have both declined to produce the chemical thionyl chloride for the Defense Department.

US officials must now decide whether to allow the Commerce Department to invoke a law dating from the outset of the Korean war that would compel the US manufacturers to comply with the military's purchase order.

Thionyl chloride is an internationally restricted ingredient needed for the production of the nerve agent used in the Army's 155 millimeter binary artillery shells. Last spring, the US administration

\section{PHARMACEUTICAL PATENTS Europe to close gap? \\ London}

NEw regulations to bring patent protection for pharmaceutical products in European Communities (EC) countries in line with the United States and Japan were launched by the European Commission last week.

Drug companies file for patents before clinical trials. But drugs are licensed only after exhaustive testing, which means that a standard 20-year patent typically has only eight years to run by the time a drug comes onto the market. The new regulations will give certificates to extend patent protection up to a maximum of 16 years from a drug's commercial launch, similar to schemes adopted recently in the United States and Japan.

If approved by ministers from EC member states, the regulations will come into force immediately, overruling national legislation. The Association of the British Pharmaceutical Industry is now urging the British government to support the proposed regulations, placing press advertisements to highlight its case.

Peter Aldhous moved successfully to block the sale of thionyl chloride by a West German company to Iran. Until several decades ago, the US Army itself produced the chemical at a now-closed facility. But a Pentagon official said that stocks of the substance were depleted earlier this year, requiring the purchase from a private vendor.

To receive a congressionally authorized $\$ 47$ million for a special weapons-modernization programme, the Army must establish that its Pine Bluffs, Arkansas, chemical-weapons production facility meets federal requirements and will open on schedule this year. To do this, Army officials say, the facility will need to procure 160,000 pounds of thionyl chloride by June.

A statement released by the Occidental Petroleum Corporation asserts that company policy prohibits it from selling or distributing chemicals "that contribute to the production of chemical weapons or illicit drugs". A similar sentiment is echoed by Gerd Wilcke, a representative for the Mobay Corporation. Wilcke says that the Army acknowledged that thionyl chloride would be used in chemical weapons when it first asked Mobay last autumn for the material. "Such a use would violate our corporate policy", Wilcke said, "and that is why we refused." Mobay's chief executive officer, N. H. Prater, has stated that his company has "no intention of violating the law" but would not make the delivery of the material without considering its legal options.

The situation is complicated because Mobay is a US subsidiary of Bayer AG, West German chemical company. In fact, given tightened West German export regulations adopted after public outcry over chemicals sold to Libya (Nature 337, $678 ; 23$ February 1989), it is conceivable that West German nationals working for the US subsidiary involved in a transaction could even be prosecuted under West German law.

Kyle Olson, a spokesperson for the US Chemical Manufacturers Association, says that the companies adopted policies on the matter as part of a voluntary international programme adopted last autumn by most of the world's major chemical companies to prevent the diversion of their products for use in chemical weapons (see Nature 341, 271; 1989).

Seth Shulman

\title{
Radiation research revamped
}

\section{Washington}

IN the last of his major changes to the troubled US Department of Energy (DOE), Energy Secretary James Watkins last week opened much of the department's health monitoring and radiationresearch activities to private investigators and US health agencies.

Long-term research into the health effects of radiation on current DOE workers will be transferred to the Department of Health and Human Services (HHS), which runs the National Institutes of Health and the Centers for Disease Control. Health data from former and current workers will be compiled in a national database and will be available to independent researchers, Watkins said at a press conference.

The moves follow the recommendations of a final report from an independent advisory panel set up by Watkins last year. The report was also released last week. Kristine Gebbie, who headed the panel, said that widespread "concerns about credibility" had dominated the committee's thinking (see Nature 344, 92; 8 March 1990). Only by shifting the responsibility for some of the more sensitive health research out of DOE can the agency avoid the perception of conflict of interest among its workers, she said.

But "merely transferring the [DOE epidemiology] program in total would overlook the facts that no employer can transfer its responsibility to protect worker and community health", the report warns. It proposes a compromise, in which 'analytic' epidemiology would be transferred to HHS, while 'descriptive' epidemiology remained within DOE.

Analytic epidemiology, as defined by the panel, is research designed to test causal hypotheses. Because this kind of analysis requires that scientists develop hypotheses without concern for the consequences should they turn out to be true, "there are limits to how well an organization can study itself", the report says. "Because the Department's role is to promote energy production, there is an inherent potential conflict between immediate production goals and health and safety goals".

Descriptive epidemiology "describes trends of risk and disease", according to the report. Such work simply describes who is getting diseases, where the diseases are most common and what may cause them. Because the work is based on straightforward statistics, the advisory panel concluded that DOE would not face a substantial credibility problem if it continued to oversee that portion of the epidemiology programme. Watkins said the report was "exactly what I wanted" and he would accept the recommendations. 